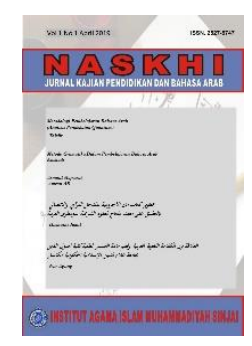

\title{
FACEBOOK SEBAGAI ALTERNATIF MEDIA PENGEMBANGAN MAHARAH KITABAH
}

\author{
Rahmat Linur $^{1}$, Mahfuz Rizqi Mubarak ${ }^{2}$ \\ ${ }^{I}$ Sekolah Tinggi Agama Islam Negeri Mandailing Natal \\ ${ }_{2}^{2}$ Institut Agama Islam Negeri Palangka Raya \\ Korespondesi Penulis. E-mail: rahmatlinur@yahoo.com,
}

\begin{abstract}
Abstrak
Artikel ini bertujuan untuk mengungkapkan peran facebook sebagai media alternatif dalam pengembangan kemampuan Maharah Kitabah para pengguna. Penelitian ini menggunakan metode kualitatif deskriptif dengan mengungkapkan berbagaimacam fenomena yang terjadi khususnya pada aspek penggunaan media sosial facebook dalam menunjang pengembangan kemampuan Maharah Kitabah. Peneliti juga menggunakan pendekatan literatur dan pernyataan dari beberapa ahli untuk memperkuat hasil penelitian, Dalam penelitian ini, Peneliti menyimpulkan bahwa facebook dapat digunakan sebagai media alternatif dalam pengembangan Maharah Kitabah. Fitur kolom status memungkinkan para pengguna untuk mengungkapkan ide, gagasan, dan pendapat mereka menggunakan tulisan bahasa Arab. hal ini dapat menumbukan kepercayaan diri mereka untuk berbahasa Arab secara aktif. Fitur komentar yang tersedia di setiap status facebook bermanfaat bagi pengguna lainnya untuk memberikan respon berbentuk pertanyaan, evaluasi, atau bahkan pujian. Di sisi lain, beberapa grup/kelompok belajar bahasa Arab yang tersedia di facebook mampu memberikan dampak positif dalam pengembangan maharah lainnya seperti Maharah Istima', Maharah Kalam, dan Maharah Qira'ah.
\end{abstract}

Kata Kunci: Facebook, Maharah kalam.

This article aims to reveal the role of Facebook as an alternative media in developing the ability of Maharah Kitabah users. This research uses descriptive qualitative method by revealing various kinds of phenomena that occur especially in the aspect of the use of social media Facebook in supporting the development of Maharah Kitabah capabilities. Researchers also use the literature approach and statements from several experts to reinforce research results. In this research, the researcher concludes that Facebook can be used as an alternative media in the development of the Maharah Kitabah. The status column feature allows users to express their ideas, ideas and opinions using Arabic writing. this can foster their confidence to actively speak Arabic. The comments feature available on each facebook status is useful for other users to provide responses in the form of questions, evaluations, or even praise. On the other hand, some Arabic learning groups / groups available on Facebook can have a positive impact on the development of other maharah such as Maharah Istima ', Maharah Kalam, and Maharah Qira'ah.

Keyword: Facebook, Maharah Kalam 


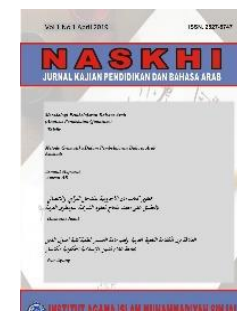

\section{NASKHI}

Jurnal Kajian Pendidikan dan Bahasa Arab

Volume 2, No. 1, 2020

ISSN (print) : 2527-5747

ISSN (online) : 2716-3369

Homepage : https://journal.iaimsinjai.ac.id/index.php/naskhi

\section{PENDAHULUAN}

Di era modern ini, media sosial sudah masuk ke segala lini kehidupan masyarakat. Masingmasing individu baik kalangan anak-anak, remaja, bahkan dewasa memiliki akun media sosial mereka masing-masing seperti Facebook, twitter, Youtube, Instagram, dan lain sebagainya. Remaja mendominasi penggunaan layanan internet. Hal ini berdasarkan hasil riset yang dilakukan Sekolah Tinggi Sandi Negara (STSN) Indonesia Bersama Yahoo menunjukkan bahwa kalangan remaja di usia 15-19 tahun mendominasi penggunaan internet di Indonesia sebanyak 64\% (Aspari, 2016). Detik.com melaporkan bahwa sampai akhir 2018, populasi dunia mencapai 7,6 miliar, sedangkan penggunaan internet sudah mencapai 4,1 miliar orang, dan yang aktif dalam bermedia sosial mencapai angka 1,8 miliar orang (Hidayat, n.d.).

Media sosial memiliki lima karakteristik yaitu: (1) Partisipasi, media sosial mendorong kontribusi dan umpak balik dari setiap orang yang tertarik. (2) Keterbukaan, media sosial sangat terbuka untuk umpan balik dan partisipasi. Keterbukaan untuk mengakses dan memanfaatkan kontenkonten yang disukai dengan tanpa hambatan. (3) percakapan, media sosial lebih baik dilihat sebagai percakapan dua arah. (4) komunitas, media sosial memungkinkan komunitas untuk terbentuk dengan cepat dan berkomunikasi secara efektif. (5) keterhubungan, sebagian besar jenis media sosial berkembang pada keterhubungan mereka, memanfaatkan link ke situs lain, sumber daya dan orangorang di dalamnya (Sindang, 2013).

Perkembangan media sosial ini tentunya tidak lepas dari pro dan kontra. Sebagaimana laporan dari Kompasiana.com bahwa media sosial memiliki dampak positif seperti (1) mempererat tali silaturrahmi keluarga, (2) kemudahan pada penyebaran informasi, (3) sebagai sumber belajar, (4) sebagai media promosi dalam berbisnis, dan lain sebagainya. Namun, media sosial juga tidak lepas dari dampak negatif seperti (1) enggan bersosialisasi dengan masyarakat sekitar, (2) candu yang berimplikasi pada berkurangnya kualitas kinerja, (3) kejahatan di dunia maya yang populer dengan istilah cyber crime, (4) pornografi, dan lain sebagainya (Pengaruh Media Sosial Bagi RemajaKompasiana.com, n.d.). Terlepas dari fenomena pro dan kontra ini, semua kembali kepada kebijakan dari masing-masing individu untuk menggunakan media sosial tersebut.

Di dunia Pendidikan, Eksistensi risert tentang penggunaan teknologi informasi seperti media sosial sebagai sumber kegiatan pembelajaran mulai marak dilakukan. Hal ini dipandang perlu mengingat perkembangan teknologi yang tak terbendung menuntut siapapun untuk tidak 'gagap' teknologi. bahkan Alfin Tofller sebagaimana dikutip oleh Haniah dalam penelitiannya mengungkapkan bahwa siapapun yang tidak menguasai ilmu pengetahuan dan teknologi, posisinya akan termarginalkan dan bukan tidak mungkin akan terhempas oleh gelombang globalisasi yang sarat dengan kompetisi (Haniah, 2014). Problem lainnya yang menuntut pelaksanaan pembelajaran berbasis teknologi informasi adalah fenomena candu generasi muda terhadap penggunaan media sosial. generasi muda abad 21 yang tidak asing dengan perkembangan teknologi diistilahkan dengan sebutan generasi Pro Gadget (Universitas Negeri Malang, Indonesia \& Susanti, 2019). Implikasi dari candu ini adalah kurangnya perhatian generasi muda khsusunya peserta didik untuk mengikuti kegiatan pembelajaran. Hal ini dibuktikan dengan hasil penelitian Mubarak, dkk di IAIN Palangka Raya yang menyatakan bahwa mahasiswa cenderung memanfaatkan kelengahan Dosen untuk memainkan media sosial atau game mobile yang ada di gadget/hp mereka di jam belajar (Mubarak et al., 2020). Maka dari itu, optimalisasi teknologi sebagai media pembelajaran sangat diperlukan untuk melahirkan suasana pembelajaran yang menarik, menyenangkan dan tidak monoton (Ahmadi, 2014).

Beberapa media sosial menjadi media alternatif yang dapat dimanfaatkan oleh pendidik dalam kegiatan pembelajaran seperti pembelajaran bahasa Arab mengingat untuk mempelajari bahasa Arab diperlukan adanya inovasi suatu pendekatan yang menarik dan menyenangkan sebagai stimulus bagi peserta didik untuk mau belajar (Takdir, 2019). Alternatif penggunaan media sosial ini dilandasi oleh luasnya sumber belajar yang tersedia (Albantani, 2019, p. 147). Sebagai contoh pada media Youtube, setiap orang dapat mengakses video bahasa Arab yang dapat menunjang kemampuan keterampilan berbahasa baik Maharah Istima', Maharah Kalam, Maharah Qiro'ah, dan Maharah Kitabah 


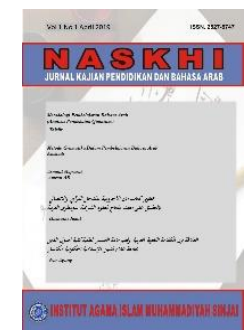

\section{NASKHI}

\section{Jurnal Kajian Pendidikan dan Bahasa Arab}

Volume 2, No. 1, 2020

ISSN (print) : 2527-5747

ISSN (online) : 2716-3369

Homepage : https://journal.iaimsinjai.ac.id/index.php/naskhi

(Albantani \& Madkur, 2017). Contoh yang lain seperti media Whatsapp juga memberikan kemudahan terhadap mahasiswa dalam mempraktekkan bahasa Arab mengingat kehidupan mahasiswa di era modern ini sangat lekat dengan perkembangan teknologi. media ini mampu meningkatkan kepercayaan diri (Self-Confidence) dan motivasi mahasiswa untuk menyampaikan pendapatnya secara lisan (Maharah Kalam) (Sa`diyah, 2019). Salah satu fitur di sosial media seperti Vlog juga terbukti mampu meningkatkan minat dan motivasi mahasiswa dalam pembelajaran Maharah Kalam mahasiswa (Mubarak et al., 2020). Dari penelitian-penelitian tersebut, dapat disimpulkan bahwa media sosial terbukti memberikan implikasi positif terhadap pembelajaran dan memberikan alternatif kemudahan bagi pendidik maupun peserta didik untuk mengembangkan kompetensi Bahasa Arab Serta memberikan solusi terhadap para pendidik. Namun, kesimpulan ini tidak sepenuhnya benar mengingat beberapa pendidik mengalami kesulitan dalam menerapkan pembelajaran berbasis IT disebabkan usia mereka yang tua dan enggan untuk menyesuaikan diri terhadap perkembangan teknologi (Mardiana \& Daniels, 2019).

Salah satu media sosial yang populer di kalangan masyarakat adalah Facebook. Beberapa tahun kebelakang media sosial facebook mendapatkan perhatian khusus pada kegiatan pembelajaran. Facebook terbukti memberikan kontribusi yang sangat signifikan pada keterampilan menulis bahasa Inggris untuk peserta didik. Facebook juga mampu meningkatkan kepercayaan diri dan kepuasan peserta didik pada pembelajaran keterampilan menulis bahasa inggris tersebut (Sirivedin et al., 2018). Dalam penelitian yang lain, fitur grup facebook memberikan kemudahan kepada para pendidik untuk membagikan bahan ajar tanpa harus membagi satu persatu ke para pendidik. peserta didik juga dapat berinteraksi dengan mudah baik peserta didik dengan pendidik/instruktur maupun dengan peserta didik lainnya dengan memanfaatkan fleksibelitas dari media sosial facebook ini (Legaree, 2014).

\section{METODE}

Penelitian ini menggunakan metode kualitatif deskriptif dengan mengungkapkan fenomena yang berkembang dalam pembelajaran khususnya pada aspek penggunaan media sosial facebook sebagai alternatif media pengembangan Maharah Kitabah. peneliti menggunakan pendekatan literatur baik cetak maupun online untuk pengumpulan data dan informasi mengenai penggunaan media sosial facebook untuk pengembangan Maharah Kitabah. selain itu, peneliti juga menyari beberapa pernyataan dari para ahli untuk mendukung pada bagian pembahasan. Pernyataan-pernyataan para ahli berasal dari jurnal nasional maupun internasional yang relevan dengan kajian yang diteliti.

\section{HASIL DAN PEMBAHASAN \\ Facebook}

Data dari Global Social Media Rangking menunjukkan bahwa Facebook Sebagai media sosial dengan jumlah pengguna aktif terbanyak Sebesar 2,45 Miliar (Global social media ranking 2019, n.d.).

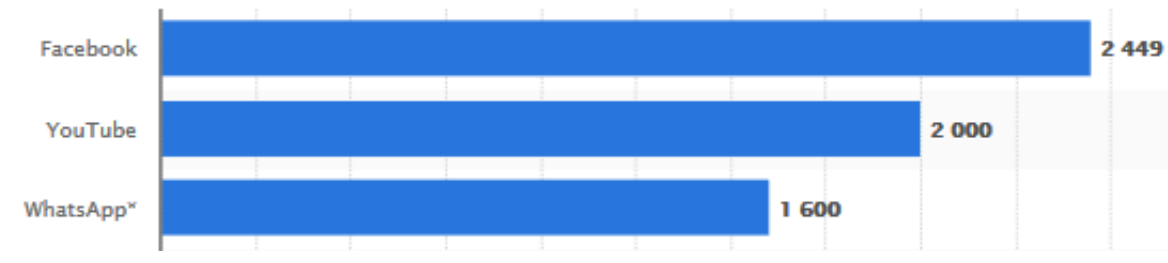

\section{Gambar 1: Statistic Pengguna Media Sosial sampai Januari Tahun 2020}

Media sosial yang dibuat oleh Marck Zukerbeck ini memfasilitasi setiap orang untuk berbagi perasaan, ide, dan pengalaman secara bebas melalui kolom status yang tersedia dengan sebuah pertanyaan "apa yang ada pikirkan?". Status yang dibagikan Dari kolom ini juga diberikan fitur 


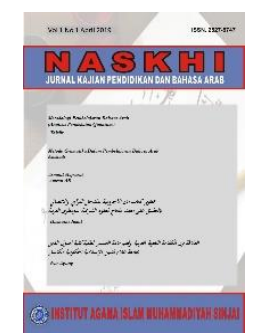

\title{
NASKHI
}

\author{
Jurnal Kajian Pendidikan dan Bahasa Arab \\ Volume 2, No. 1, 2020 \\ ISSN (print) : 2527-5747 \\ ISSN (online) : 2716-3369 \\ Homepage : https://journal.iaimsinjai.ac.id/index.php/naskhi
}

komentar yang memungkinkan para pengguna media sosial lainnya untuk mengomentari status tersebut. Selain fitur status dan komentar, Facebook juga memiliki fitur pesan (Mesengger) yang digunakan untuk mengirim pesan tulisan satu sama lain. Fitur Mesengger ini juga dilengkapi dengan fasilitas rekam audio, video, dan gambar sehingga pesan yang dikirim tidak hanya sebatas pesan secara tertulis, namun juga bisa pesan audio suara, pesan berbentuk video, dan gambar (Bin Tahir, 2013).

Beberapa tahun belakangan ini, eksistensi penggunaan facebook sebagai media pembelajaran telah merambah luas di kalangan Nasional maupun International. Upaya penggunaan facebook sebagai media pembelajaran ini bukan tanpa alasan. Selain beberapa alasan yang telah disebutkan peneliti di latar belakang, Sanchez dalam penelitiannya mengungkapkan bahwa facebook merupakan salah satu media sosial (Social Network Site, SNS) yang sangat populer di kalangan peserta didik di seluruh dunia (Arteaga Sánchez et al., 2014). Penggunaan media ini juga bertujuan untuk menyadarkan kepada seluruh masyarakat khususnya kalangan peserta didik bahwa media sosial tidak hanya digunakan sebagai pengungkapan jati diri atau informasi pribadi kepada khalayak luas melainkan juga memiliki manfaat lain pada bidang Pendidikan (Hew, 2011). Salah satu implikasi dari penggunaan Facebook pada pembelajaran adalah terciptanya ruang belajar virtual yang interaktif serta mampu mendorong reflektifitas peserta didik untuk aktif dan percaya diri pada kegiatan pembelajaran (Ramdani \& Widodo, 2019).

\section{Maharah Kitabah}

Dalam empat keterampilan berbahasa Arab yaitu Mendengar (Istima'), Berbicara (Kalam), Membaca (Qira'ah), dan Menulis (Kitabah) memiliki hubungan yang tak terpisahkan. Misalnya, keterampilan menyimak berkontribusi terhadap kemampuan berbicara dan sebaliknya, dan pada gilirannya kedua kemampuan tersebut diperkuat oleh kemampuan membaca. Hasil dari proses menyimak, berbicara, dan membaca diinpretasikan dalam bentuk tulisan (Maharah Kitabah) (Huda, 2016). Dari penjelasan tersebut, dapat disimpulkan bahwa keterampilan menulis (Maharah Kitabah) merupakan keterampilan komprehensif yang harus ditopang dengan keterampilan-keterampilan lainnya.

Maharah Kitabah berorientasi pada kemampuan mengekspresikan berbagai macam pikiran, gagasan, pendapat, dan perasaan secara tertulis. Di sisi lain, pembelajaran Maharah Kitabah bertujuan untuk meningkatkan kemampuan intelektual, kematangan emosional, dan kematangan sosial terhadap peserta didik (Efendi, 2008, p. 326).

Maharah Kitabah memiliki beberapa unsur dalam pembelajaran bahasa Arab: Pertama, menulis dalam lingkup karangan (deskripsi, narasi, argumentasi, dan persuasi) yang dinamakan dengan At-Ta'bir at-Tahririy atau Al-Insya'. Kedua, menulis dalam lingkup bentuk huruf dan susunan standar dengan cara didiktekan yang populer dengan istilah Al-Imla'. Ketiga, menulis dengan bentuk tulisan yang indah sehingga dapat dibaca dan dinikmati nilai seninya. Unsur yang terakhir ini dikenal dengan istilah Al-adab dan Al-Khath (Huda, 2016).

\section{Facebook Sebagai Media Alternatif Pengembangan Maharah Kitabah}

Sebagaimana yang telah disebutkan sebelumnya bahwa facebook merupakan media sosial yang dibuat oleh Marck Zukerbeck sekaligus menjadi media sosial dengan jumlah penggunan aktif terbanyak di seluruh dunia. Facebook memiliki kolom status yang memungkinkan setiap penggunanya untuk mengekspresikan segala sesuatu yang terjadi pada diri penggunanya dengan bentuk tulisan naratif. Pengguna lain juga dapat memberikan sumbangsih pemikiran berbentuk komentar terhadap pembuat status pada kolom komentar yang disediakan oleh facebook. Komentar yang diberikan bisa berbentuk masukan atau evaluasi. Dari sini, peneliti menyimpulkan bahwa kolom status merupakan stimulus yang akan memancing respon dari para penggunaan lainnya untuk mengomentari di kolom komentar. Hal ini memungkinkan terjadinya sebuah pertukaran ilmu pengetahuan (Maulidiyah et al., 2018)

Dalam aspek Pendidikan khususnya pada pendidikan Bahasa Arab, kolom status memungkinkan para pengguna bahasa Arab untuk menuangkan segala ide dan gagasannya melalui 


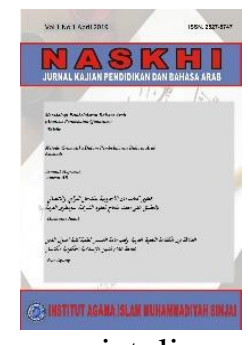

NASKHI

Jurnal Kajian Pendidikan dan Bahasa Arab

Volume 2, No. 1, 2020

ISSN (print) : 2527-5747

ISSN (online) : 2716-3369

Homepage : https://journal.iaimsinjai.ac.id/index.php/naskhi

narasi tulisan deskriptif berbahasa Arab. Hal ini dapat dibuktikan pada beberapa status pengguna facebook yang peneliti temukan sebagaimana berikut:

lainnya

18 Maret pukul 11.07

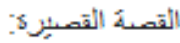

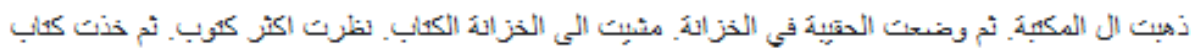

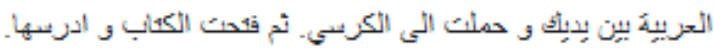

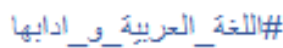

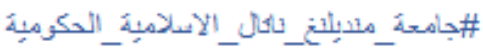

Lihat Terjemahan

(1) 20

11 Komentar

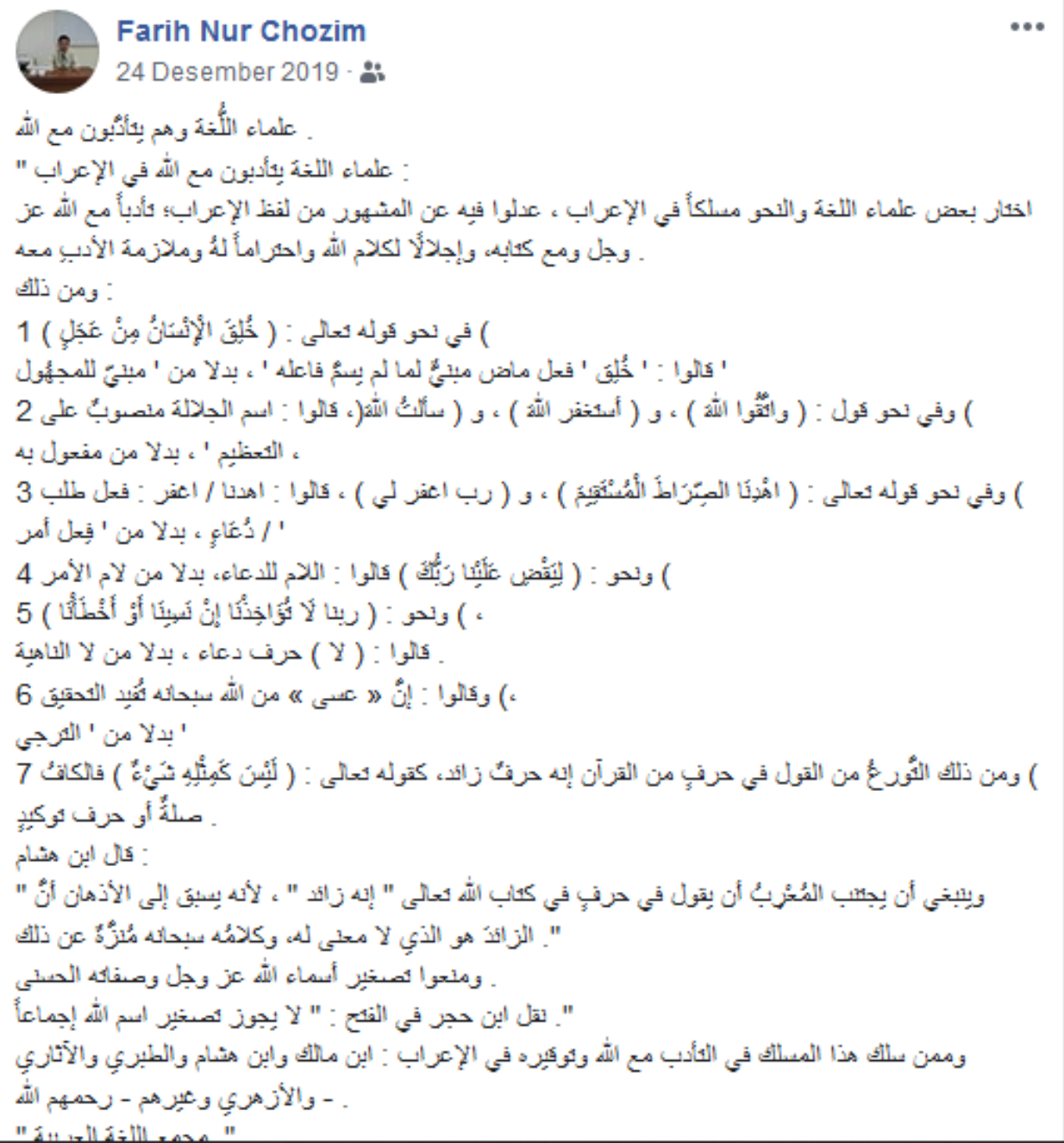




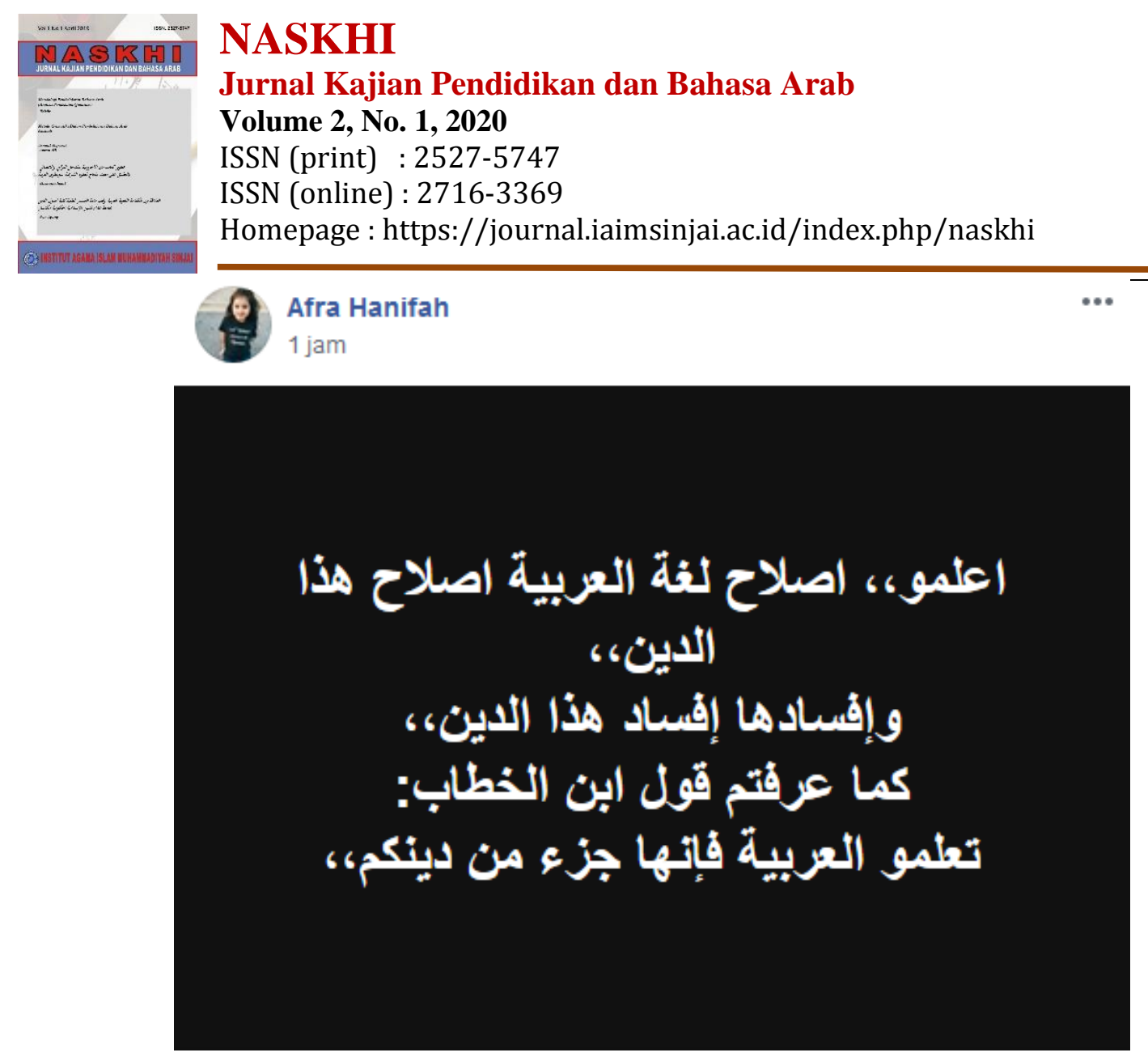

Gambar 2: Hasil ide, gagasan, dan pendapat yang ada di Facebook

Dari beberapa status di atas, dapat dilihat bahwa beberapa pengguna memanfaatkan kolom status sebagai media mengungkapkan gagasan, ide, atau pendapat mereka dengan tulisan bahasa Arab. hal ini sangat bagus untuk meningkatkan kepercayaan diri mereka dalam menulis berbahasa Arab (Maharah Kitabah).

Di sisi lain peneliti juga berpendapat bahwa gagasan dengan tulisan berbahasa Arab yang dituangkan para pengguna di kolom status mampu menjadi stimulus dari para pengguna lainnya. Adapun respon yang diberikan dari pengguna lainnya bisa berbentuk koreksi kesalahan, pertanyaan atau bahkan pujian sebagaimana berikut:

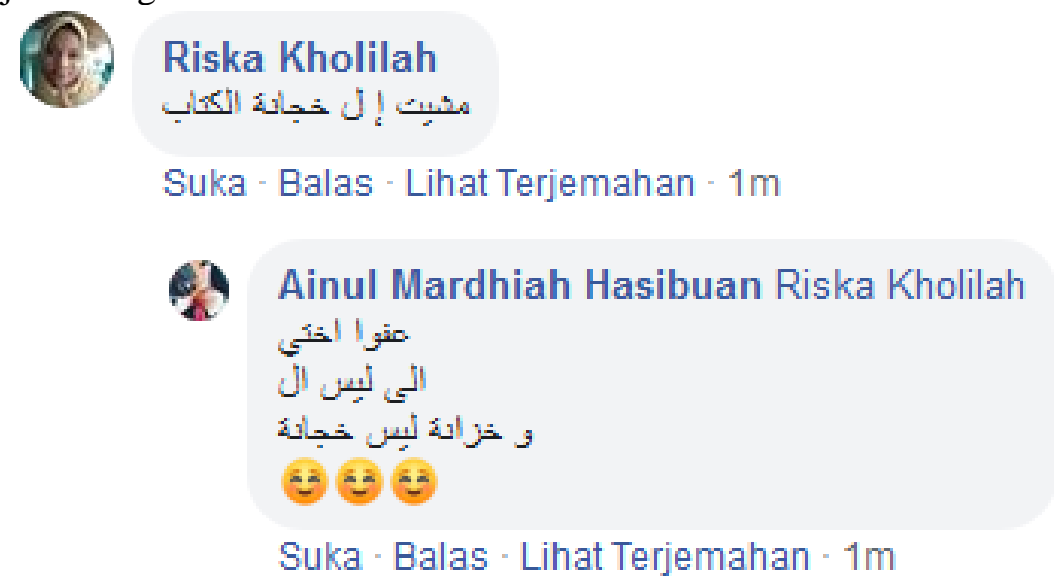




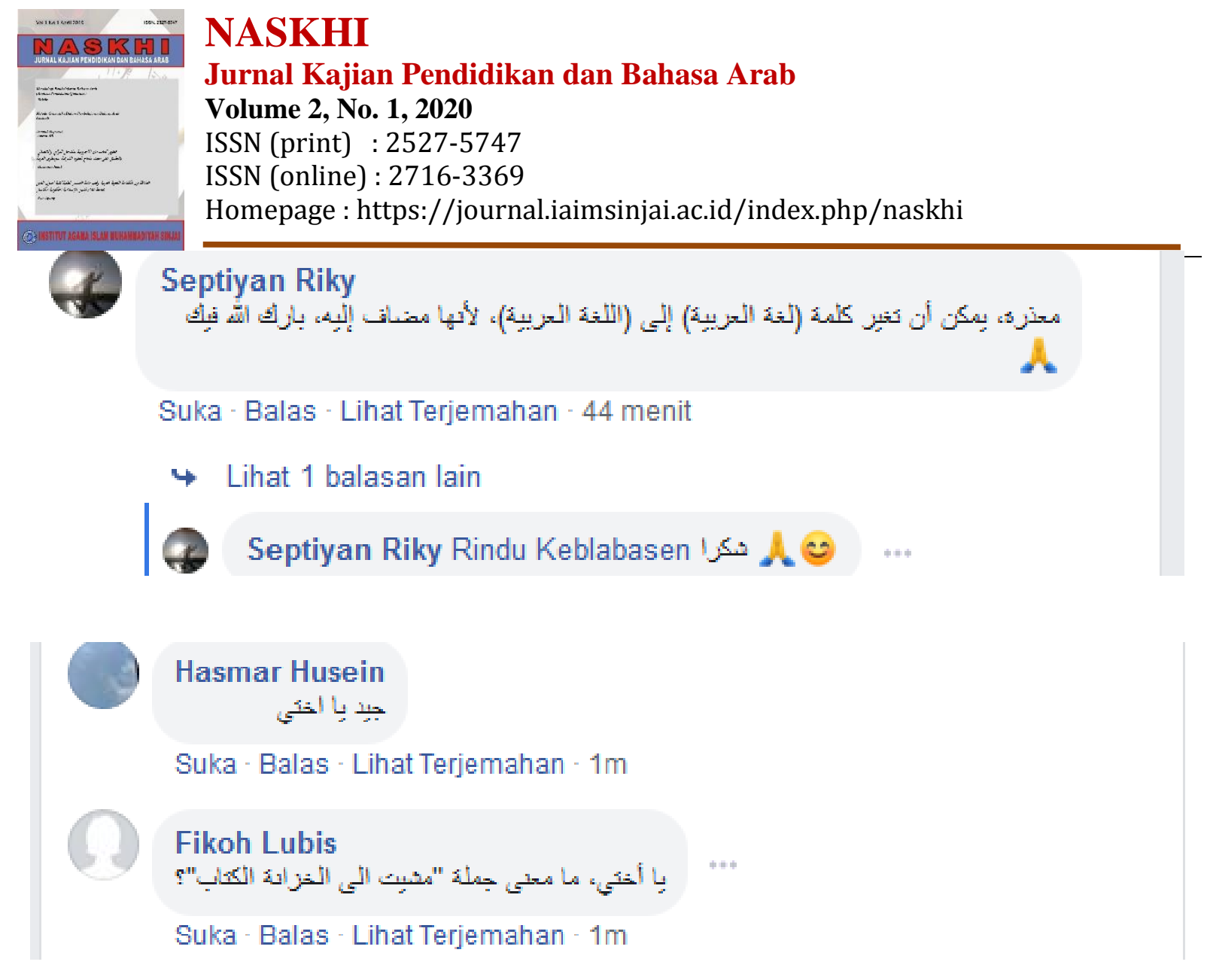

Gambar 3: Hasil respon para pengguna Facebook

Dari beberapa hasil temuan tersebut, peneliti menyimpulkan bahwa media sosial facebook dapat dijadikan sebagai media alternatif yang dapat digunakan oleh semua orang di manapun dan kapanpun dalam pengembangan bahasa Arab khususnya pada kemampuan Maharah Kitabah. Ide atau gagasan yang dituangkan para pengguna menggunakan bahasa Arab sekaligus ditunjang dengan komentar-komentar yang edukatif memiliki dampak positif pada kemampuan kognitif, afektif, dan psikomotorik semua pengguna facebook.

Di sisi lain, dalam penelusuran peneliti di media sosial facebook peneliti juga menemukan beberapa grup/kelompok yang dapat menunjang kemampuan berbahasa Arab para pengguna. Grup/kelompok yang tersedia di facebook dibuat oleh beberapa Lembaga pembelajaran bahasa Arab baik secara formal maupun informal.

Kelompok Belajar
Bahasa Arab
9 Grup Publik
Tentang
Diskusi
Pengumuman
Anggota
Acara
Video
Foto

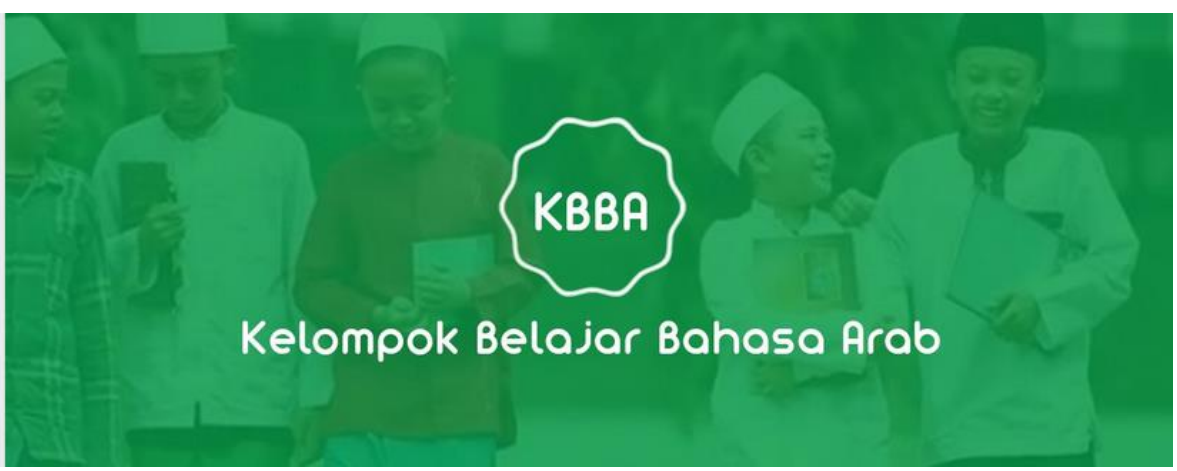




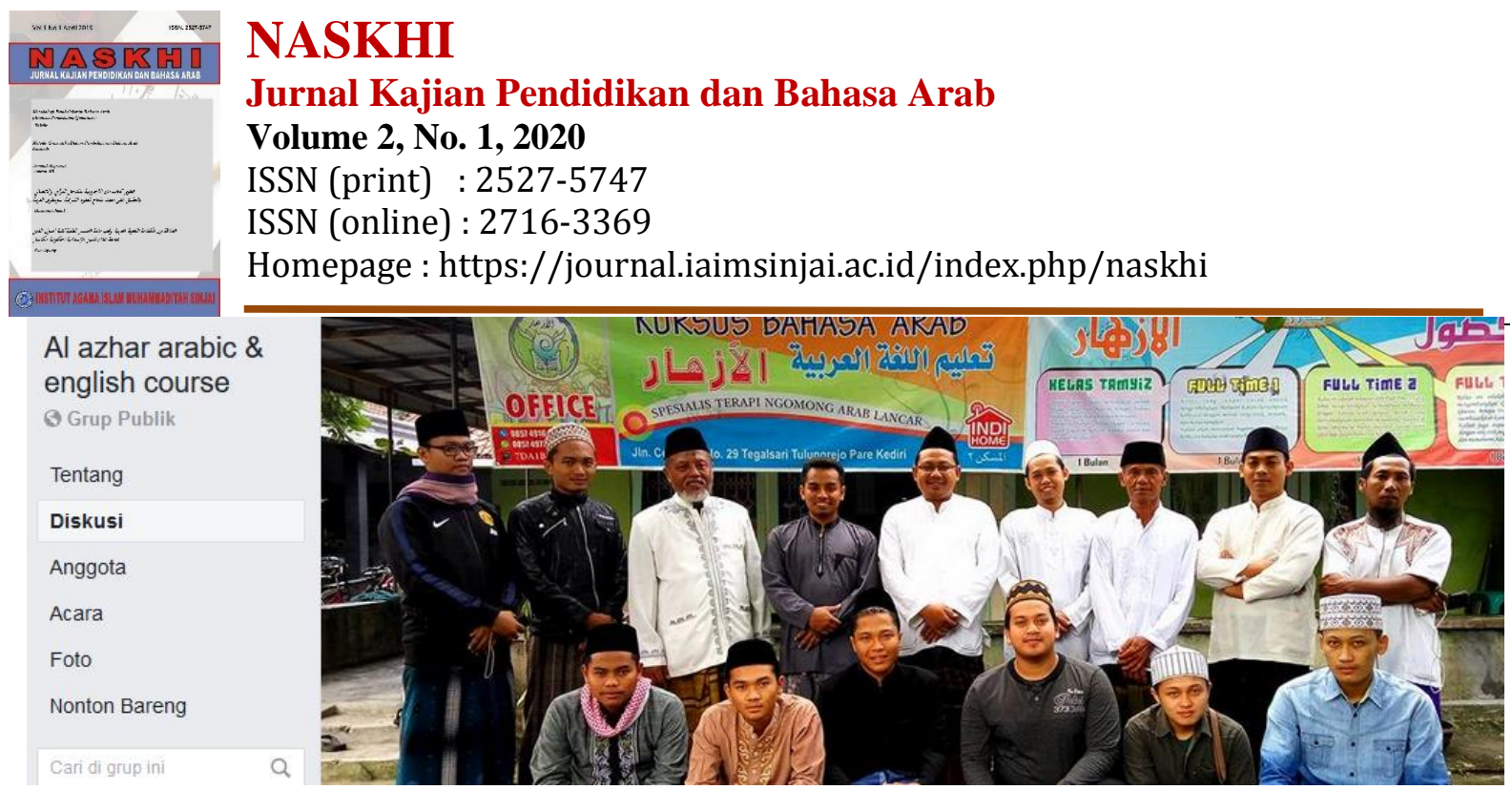

Gambar 4: Grup/Kelompok belajar bahasa Arab di media sosial Facebook

Melalui grup/kelompok yang tersedia di facebook memungkinkan para pengguna untuk saling berinteraksi secara aktif mengenai ide dan pengalaman mereka menggunakan tulisan berbahasa Arab. peneliti juga menemukan bahwa pengalaman-pengalaman belajar bahasa Arab yang dibagikan para penggunan melalui grup/kelompok tidak hanya berbentuk tulisan akan tetapi bisa berbentuk video. Video ini tidak hanya bermanfaat untuk pengembangan Maharah Kitabah saja melainkan untuk beberapa Maharah lainnya seperti Maharah Istima', Maharah Kalam, dan Maharah Qira'ah.

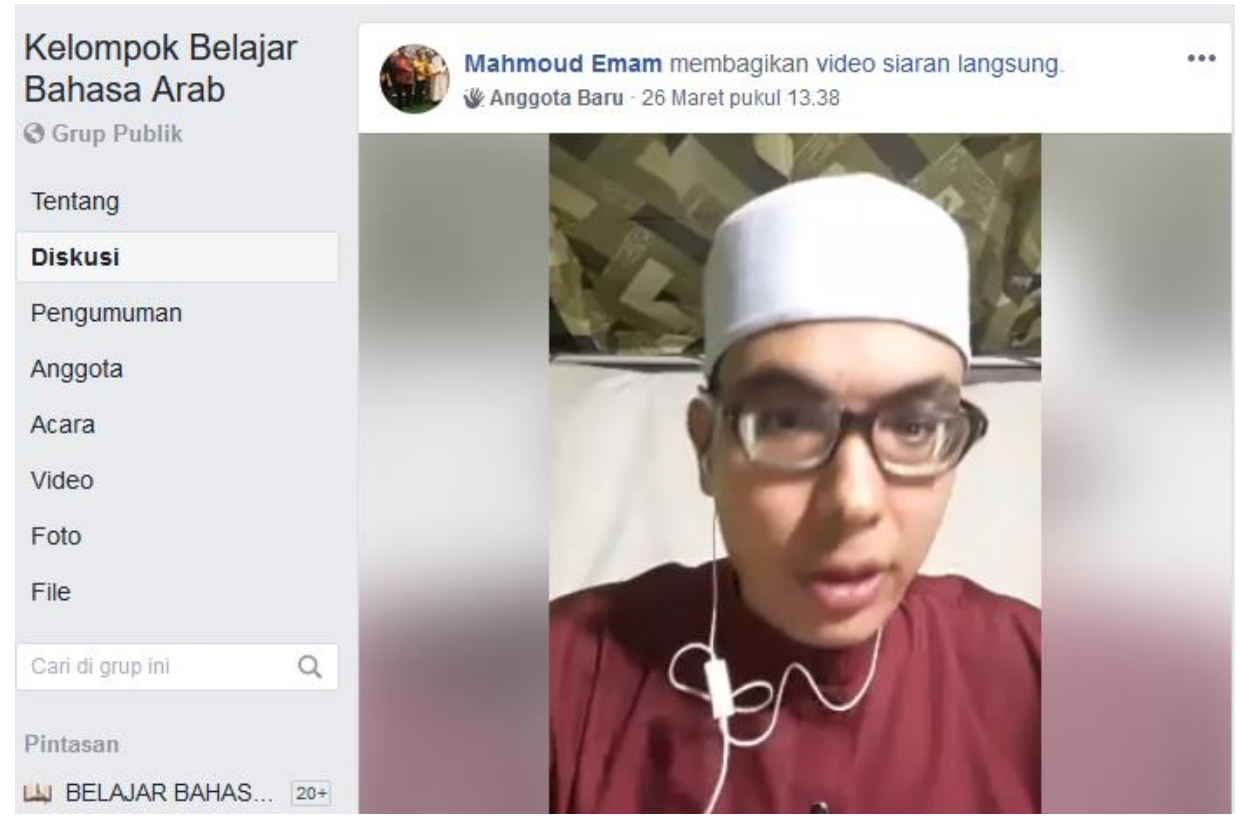




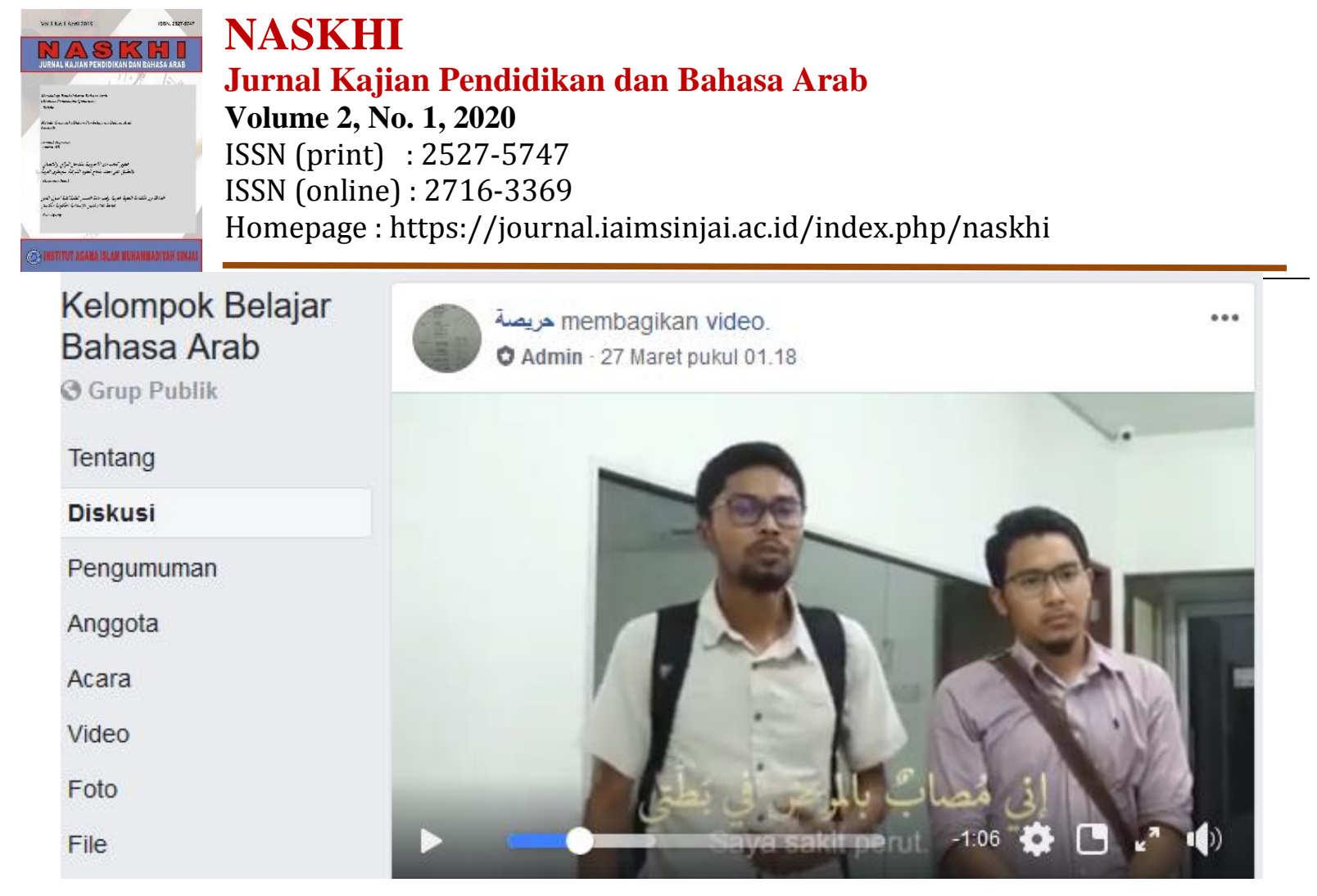

Gambar 5: Proses sharing ilmu bahasa Arab di Grup/Kelompok Facebook

\section{SIMPULAN}

Berdasarkan hasil penelitian ini, peneliti menyimpulkan bahwa facebook dapat digunakan sebagai media alternatif dalam pengembangan Maharah Kitabah. Fitur kolom status memungkinkan para pengguna untuk mengungkapkan ide, gagasan, dan pendapat mereka menggunakan tulisan bahasa Arab. hal ini dapat menumbukan kepercayaan diri mereka untuk berbahasa Arab secara aktif. Fitur komentar yang tersedia di setiap status facebook bermanfaat bagi pengguna lainnya untuk memberikan respon berbentuk pertanyaan, evaluasi, atau bahkan pujian. Di sisi lain, beberapa grup/kelompok belajar bahasa Arab yang tersedia di facebook mampu memberikan dampak positif dalam pengembangan maharah lainnya seperti Maharah Istima', Maharah Kalam, dan Maharah Qira'ah. Peneliti berharap bagi para pengguna agar tidak hanya memanfaatkan media sosial facebook sebatas mengungkapkan jati diri pribadi saja akan tetapi dapat dioptimalkan pada aspek kemampuan berbahasa baik bahasa Arab maupun bahasa Inggris sebagaimana hasil penelitian yang telah dilakukan sebelumnya. Peneliti juga berharap agar penelitian ini bisa menjadi rujukan untuk penelitian-penelitian selanjutnya yang bermuara pada media pembelajaran.

\section{Daftar Pustaka}

Ahmadi, A. (2014). Optimalisasi Pemanfaatan Laboratorium Bahasa Dalam Meningkatkan Pembelajaran Bahasa Arab. Al-Ta'rib: Jurnal Ilmiah Program Studi Pendidikan Bahasa Arab IAIN Palangka Raya, 2(1), 67-74. https://doi.org/10.23971/altarib.v2i1.1534

Albantani, A. M. (2019). Social Media as Alternative Media for Arabic Teaching in Digital Era. ALSINATUNA, 4(2), 148-161. https://doi.org/10.28918/alsinatuna.v4i2.2043

Albantani, A. M., \& Madkur, A. (2017). Musyahadat Al Fidyu: Youtube-Based Teaching and Learning of Arabic as Foreign Language (AFL). Dinamika Ilmu, 17(2), 291-308. https://doi.org/10.21093/di.v17i2.854

Arteaga Sánchez, R., Cortijo, V., \& Javed, U. (2014). Students' perceptions of Facebook for academic $\begin{array}{llll}\text { purposes. } \quad \text { Computers } \quad \text { E } & \text { 138-149. }\end{array}$ https://doi.org/10.1016/j.compedu.2013.08.012 


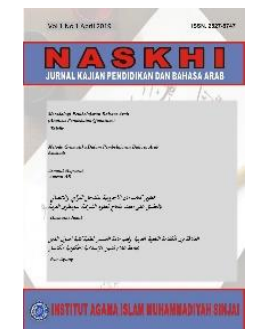

\section{NASKHI}

\section{Jurnal Kajian Pendidikan dan Bahasa Arab}

Volume 2, No. 1, 2020

ISSN (print) : 2527-5747

ISSN (online) : 2716-3369

Homepage : https://journal.iaimsinjai.ac.id/index.php/naskhi

Aspari, A. (2016). Media Sosial Sebagai Media Pembelajaran Bahasa Pada Masyarakat Modern. Prosiding, Simposium Nasional Ilmu Pengetahuan Dan Teknologi (SIMNASIPTEK).

Bin Tahir, S. Z. (2013). Penggunaan Facebook Untuk Meningkatkan Kemampuan Menulis Teks Deskriptif Mahasiswa Fkip Jurusan Bahasa Inggris Di Universitas Iqra Buru. Jurnal Prospek, 15(1), 68-76.

Efendi, A. (2008). Bahasa \& Sastra Dalam Berbagai Perspektif. Tiara Wacana.

Global social media ranking 2019. (n.d.). Statista. Retrieved March 9, 2020, from https://www.statista.com/statistics/272014/global-social-networks-ranked-by-number-ofusers/

Haniah, H. (2014). Pemanfaatan Teknologi Informasi Dalam Mengatasi Masalah Belajar Bahasa Arab. Al-Ta'rib: Jurnal Ilmiah Program Studi Pendidikan Bahasa Arab IAIN Palangka Raya, 2(1). https://doi.org/10.23971/altarib.v2i1.588

Hew, K. F. (2011). Students' and teachers' use of Facebook. Computers in Human Behavior, 27(2), 662-676. https://doi.org/10.1016/j.chb.2010.11.020

Hidayat, A. (n.d.). Demokrasi Digital Era Media Sosial. detiknews. Retrieved February 27, 2020, from https://news.detik.com/kolom/d-4569835/demokrasi-digital-era-media-sosial

Huda, N. (2016). Komponen-Komponen Pembelajaran Al-Kitâbah Bahasa Arab. Al Mahāra: Jurnal Pendidikan Bahasa Arab, 2(1), 1-22. https://doi.org/10.14421/almahara.2016.021-01

Legaree, B. A. (2014). Using Facebook to Engage Microbiology Students Outside of Class Time. Journal of Microbiology \& Biology Education, 15(2). https://doi.org/10.1128/jmbe.v15i2.713

Mardiana, H., \& Daniels, H. K. (2019). The Role of Rationality and Technological Change in Learning Process. Indonesian Journal of Learning Education and Counseling, 1(2), 151-159. https://doi.org/10.31960/ijolec.v1i2.64

Maulidiyah, M., Arfiyanti, R., \& Mudopar, M. (2018). Penerapan Model Pembelajaran Kontekstual dengan Menggunakan Media Facebook dalam Pembelajaran Menulis Puisi pada Siswa SMP. Deiksis: Jurnal Pendidikan Bahasa dan Sastra Indonesia, 5(2), 91-101. https://doi.org/10.33603/deiksis.v5i2.1162

Mubarak, M. R., Wahdah, N., Ilmiani, A. M., \& Hamidah, H. (2020). Penggunaan Vlog Dalam Pembelajaran Mahārah Kalām. Al Mi'yar: Jurnal Ilmiah Pembelajaran Bahasa Arab dan Kebahasaaraban, 3(1), 109-126. https://doi.org/10.35931/am.v3i1.209

Pengaruh Media Sosial Bagi Remaja-Kompasiana.com. (n.d.). Retrieved February 27, 2020, from https://www.kompasiana.com/amipratiwi18/5902e5578c7e61e71b2c3016/pengaruh-mediasosial-bagi-remaja

Ramdani, J. M., \& Widodo, H. P. (2019). Student teachers' engagement in Facebook-assisted peer assessment in an initial teacher education context: Speaking 2.0. Journal of Education for Teaching, 45(3), 348-352. https://doi.org/10.1080/09589236.2019.1599503

Sa`diyah, H. (2019). Upaya Menumbuhkan Self-Confidence Berbicara Bahasa Arab Mahasiswa Melalui Grup Whatsapp. Al Mi'yar: Jurnal Ilmiah Pembelajaran Bahasa Arab dan Kebahasaaraban, 2(2), 149-164. https://doi.org/10.35931/am.v2i2.119

Sindang, E. (2013). Manfaat Media Sosial dalam Ranah Pendidikan dan Pelatihan. Jakarta: Pusdiklat $K N P K$. 


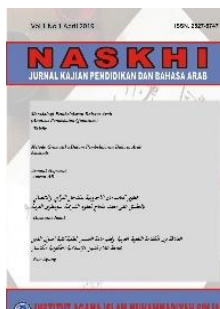

NASKHI

Jurnal Kajian Pendidikan dan Bahasa Arab

Volume 2, No. 1, 2020

ISSN (print) : 2527-5747

ISSN (online) : 2716-3369

Homepage : https://journal.iaimsinjai.ac.id/index.php/naskhi

Sirivedin, P., Soopunyo, W., Srisuantang, S., \& Wongsothorn, A. (2018). Effects of Facebook usage on English learning behavior of Thai English teachers. Kasetsart Journal of Social Sciences, 39(2), 183-189. https://doi.org/10.1016/j.kjss.2018.03.007

Takdir, T. (2019). Metodologi Pembelajaran Bahasa Arab : Jurnal Naskhi: Jurnal Kajian Pendidikan Dan Bahasa Arab, 1(1), 1-7.

Universitas Negeri Malang, Indonesia, \& Susanti, E. D. (2019). Project Based Learning: Pemanfaatan Vlog Dalam Pembelajaran Sejarah Untuk Generasi Pro Gadget. Sejarah dan Budaya Jurnal Sejarah Budaya dan Pengajarannya, 13(1), 84-96. https://doi.org/10.17977/um020v13i12019p084 